\title{
Occupational Health Problems Faced By Female Beedi Workers at Khajamalai, Trichy District, Tamil Nadu
}

\author{
*S.SRINIVASAN, **Dr. P.ILANGO \\ * (Guest Lecturer, Social Work, Bharathidasan University, Trichy, Tamil Nadu, India) srinivasan102@gmail.com \\ ** Head \& Professor Department of Social Work, Bharathidasan University, Trichy. pon.ilango@gmail.com
}

\begin{abstract}
This study aimed at gaining insight into the "Occupational Health Problems Faced by Female Beedi Workers at Khajamalai, Trichy. The research design used for this study is descriptive. The research selected 50 families for the study using a purposive sampling method. Only those female heads of the families who were involved in Beedi work and who were willing to answer the schedule were included for the study. The main objective of the study was to know the working conditions, health status. Most of the respondents 62 percent had work for less than 20 days. Therefore their earning capacity was also less. Majority 72 percent of the respondents were working for contractors which showed that they were subjected to exploitation. 46 percent of the respondents rolled 31-40 bundles daily. This shows that respondents were involved in very hard work. Majority $\mathbf{7 6}$ percent of the respondents stated that they had health problems. Majority $\mathbf{7 0}$ percent of the respondent stated that their health problems were due to their occupation. Majority $\mathbf{7 6}$ percent of the respondents expressed that they had a spouse who was alcoholic and as a result.
\end{abstract}

Index Terms- Occupation, Health, Female, Beedi workers, Unorganized

\section{INTRODUCTION}

$\mathrm{T}$ The Beedi and Cigar industry employs thousands of people, most of who work under conditions that are as armful to their health. They spend hours blending or rolling tobacco in unhygienic, dingy and overcrowded places having little facilities for drinking water, toilet, washing or even first aid. The working hours are often interminable and at times even child workers are made to slog for long hours in violation of the law.

The employers who make fortune from the sale of Beedi and cigar often turn a blind eye to the plight of the workers i.e. the people who add value to the product. They take advantage of the poverty of the workers, their lack of education and unity, to perpetuate exploitation. The loopholes of the Factories Act, 1948 manufactures have devised ways such as splitting their organizations into smaller units or distribution of work in private households, to ignore its provisions. Since workers are illiterate, and in most cases unorganized and the law does not define the nature of the employer - employer relationship, the Factories Act has not helped much in removing the problems of the workers engaged in the Beedi and cigar manufacturing industry.

Beedi rolling is one of the major informal sector activities in India. The government of India estimates that there are about 4.4 million workers in this industry. The majority are home based women workers who live under the poverty line. Therefore, there is a need to improve the living and working conditions as well as to promote decent employment and income opportunities for women Beedi rollers.

\section{Methodology}

The researcher used a descriptive design. The sample for the study comprised of female Beedi workers. The size of the sample was 50 female Beedi workers. The sample selected comprised of 50 female Beedi workers. Purposive random sampling technique was used for selecting the sample. Only those female heads of the families who were involved in Beedi work and who were willing to answer the schedule, were included for the study.

\section{CONDITION OF BEEDI WORKERS}

The occupational life of Beedi workers are characterized by low wages, piece rated remuneration, lack of social security and absence of organization. The Beedi workers are in the clutches of contractors and sub contractors. The contractors are the suppliers of raw materials as well as collectors of the final products. Beedi workers are usually home based workers. The condition of Beedi workers today as well as in the past, has not been very conducive. The making of Beedi is an industry widely is spread all over the country.

Beedi rolling is party carried on in the homes but mainly in whorkshops in the bigger cities and towns. Many of these places are small airless boxes often without and windows, where workers are crowded together. They usually sit on damp mud floors. Payment is almost universally made on pice rate basis. Many smaller workshops are open day and night. Regular intervals for meals and weekly holidays are generally non - existent. 
Beedi workers are paid Rs. 25 - 28 per thousand Beedis. For making 1000 beedis the workers are provided 750 gm leaves and 250 gram tobacco. The contractors reject those Beedis which they feel are not rolled properly.

Beedi is a kind of little cigarate made of tendu leaves (instead of paper) tobacco. According to a conservative estimate more than 6 million persons are engaged in Beedi making processing and allied works. The majority of them are home based workers and the rest are factory workers. They are very poorly paid and deprived of all the benefits.

According to the Parliamentary standing committee on subordinate legislation, 20 million labourers and 6 million farmers are engaged in cultivation of Tobacco.

\section{STATUS OF BEEDI WORKERS}

Timber Basu (1977) in his article entitled Beedi workers of Calcutta explores the general working conditions of the Beedi workers. He describes the Beedi workers in rural areas as bonded labours. They do not have any union to fight for their rights and do not get the basic requirements like, provident fund, bonus and other relief measures available them. A detailed study had been done in Kerela on Beedi workers by Mohan Doss (1984). He has analyzed the economic conditions of Beedi workers in Kerela. Their problems are heavy work load, low wages, poor savings, heavy debts and occupational hazards. He has examined the piece rate and wage differentiates under the following heads.

1. Regional variation

2. System wise variation

3. Brach wise variation

4. Qualitative variation

A Commission (1998) was set up by the Tamilnadu government to find out the conditions of unorganized sector. According to that commission report, most of the Beedi workers are women and majority of them carryout their work at home. Their work consists of acquiring the materials, cutting the tendu leaves, tying them with thread and binding them into bundles.

Surya Narayana Rao president of the Central Indian Beedi working association states (1998) that Beedi workers of whom quite a large number are women, are treated like bonded labourers. He states that there are seventy one lakh workers in Karanataka, five lakhs in Tamilnadu fifteen lakh of workers in Kerala. They invariably work anywhere between 10 - 16 hours daily. They live under deplorable conditions and are exploited very much.

A survey was conducted between June and October 1987 to collect social economic and demographic data. The village on kaviyour is situated in the southern district of Tirunelveli. The total poplation at the time of survey was about thousand five hundred. The majority of the village population i.e. seventy percent or more have been involved in producing Beedies. The entire family is involved in the process.

A study conducted in Kerala has revelaled that abut thirty six percentage of the workers reported suffering from one or more diseases and ninety five percent believed that it was caused by tobacco fumes ( Mohandass 1988 ) TB, Asthma, and cancer are common diseases that attack Beedi workers.

Dr. G. Kannabiran (1992) president of the All India Beedi Tobacco and cigar works federation, at a vertical workshop on status of children and women in Beedi industry, organized by the Indian council for child welfare (ICCW) said it was unfortunate that the government had not evinced interest in the enforcement of the Beedi and cigar workers act 1996.

The Beedi factors owners have figured among the top 10 highest income tax in the country but ironically their wealth has been earned through exploitation of the poor. The Beedi industry depends to a great extent on child labour and bonded child labour which is an offshoot of poverty in society but this children are not paid their full wages, because of the shortage of Beedi leaves given to them by agents who act as middlemen between the factory owners and the workers. While the Beedi workers are eligible for a minimum wage of Rs. 37.88 for thousand Beedies only twenty percent of them get this wage.

Dr. Kanabiran has said that, such unscrupulous exploitation of the poor workers including women of children could be ended if the government sincerely implemented the Beedi and cigar workers (working conditions) act and the factory owners should periodically furnish the government with the latest list of agents through whom they operate but this clause is followed more in breach than in observance.

The All India Beedi Tobacco and cigar worker federation has placed before the government the demand for abolition of contract labour system and for commitment on the part of the government not to allow children to be engaged in the industry. Much of the ills revolving round child labour exploitation could be avoided by getting the principal employers to directly give work to the agents with out involving the latter as middle men the government should convene a meeting among government officials and 
representatives of the industry and labour, to thrash out the problems affecting the industry. It is reported by the municipal office at Thirunelveli that the majority of female workers are engaged in Beedi works $(82.14 \%)$

According to the report the four main steps women are involved in the production of Beedi are

Rewinding the tread

Cutting the Beedi leaves

Rolling the Beedi

Folding the Beedi head.

All the studies have highlighted the issues concerning workers involved in Beedi making.

\section{RIGHTS OF BEEDI AND CIGAR WORKERS}

A few state governments have indeed made efforts to ensure social justice to the workers by enacting special laws for regulating the conditions or work of these labourers, but in vain. Because of the highly mobile nature of the industry manufacturers have moved from the area where any such law is in force to places where no such law exists. The efficacy of these two sets of law in ensuring the welfare of the workers has thus been far from satisfactory. To fill the void the union government felt it necessary to formulate a central legislation that would deal exclusively with the workers, welfare and commensurate with the objective of uprooting exploitation found to be exiting in the society. In pursuance of this objective the Beedi and Cigar Workers (Conditions of Employment) Act, 1966 came into being.

This act basically seeks to formulate a code of rules and regulation regarding the control and management of the industry to minimize exploitation of the workers. It also tries to improve the working condition of the labourers and provide for their welfare. While on the one hand the Act enjoins certain duties and responsibilities on the employer regarding the workers welfare and other facilities, it also forbids him from doing certain acts.

A person is considered an employee if (a) he or she is employed directly or through any agency (contractor) in any skilled, unskilled, manual or clerical work, or (b) he or she is given raw materials by an employer or a contractor for making Beedi or cigar or both at home (home worker).

In relation to contract labour, he is the principal employer. In respect of other labour, it is the person who has ultimate control over the affairs of the establishment. It is that one who holds a valid license issued under this Act to use or allow being used any place or premises as industrial premises. The application for license must specify the maximum number of employees proposed to be employed at any time of the day in the place or premises and shall be accompanied by a plan of the plan or premises. The license granted under this Act is normally valid only for the financial year in which it is granted. However, it may be renewed if the authorities are satisfied that the employer has complied with the provisions of the Act and rules.

The Act stipulates that every industrial premise should be kept clean and free of any foul dour emanating from any drain or latrine. The employer should maintain such standards of cleanliness, including white washing, colour washing, varnishing or painting. The employer must provide for good lighting and ventilation of the room or the place of work and must take measures so that workers do not have to inhale dust, fume or other impurities which are hazardous to health.

Under the Act it is also the duty of the employer to see to it that workers get sufficient supply of pure drinking water and adequate number of latrine and urinals for both male and female workers. The actual number of such utilities may be specified by the state government. The Act says the employer shall provide for washing facilities for the workers especially where blending or sieving or both of tobacco warming of Beedi in hot oven is carried on. Under the Act, the State Government may make it compulsory for the employer to maintain a canteen in the premises where more than 250 people work. First Aid facility shall be provided as may be prescribed.

The Act makes it binding on the employer to maintain a room or rooms adequately lighted clean and well ventilated for the use of children of the women employees if the number of such employees exceeds 50. The children must be kept under the care of women trained for this purpose and the mothers should be provided with facilities to be able to feed their children at intervals.

The employers shall not ask any employee to work more than nine hours a day or for more than forty eight hours a week. Adult employees may be allowed to work overtime on payment of overtime wages, but in any day and in the aggregate, fifty four hours a week. However, the law does not apply on home workers who may work for more than nine hours or less than nine hours a day. (Mangalore Ganesh Beedi Vs UOI, 1974 SCC 850)

The periods of work of an employee, inclusive of his internals for rest, shall not be spread over more than ten and a half hours in any day. However, for reasons specified in writing, the chief inspector may extend the spread over to twelve hours. 
Any employees who works overtime is entitled to wages at the rate of twice his ordinary rate of wages. The Act says that the employer must maintain and properly display a notice of periods of work during which the employees are required to work. No employee shall be employed otherwise than in accordance with the notice displayed.

Every industrial premise shall remain closed expect for wetting of Beedi or tobacco leaves, on one specified day in a week. An employer, however, may alter the day with previous written permission of the chief inspector but only once in three months.

The Act prohibits overcrowding of any room in any industrial premises to an extent that can be injurious to the health of other workers. In other words at least 4.5 cubic meters of space should be provided for every person employed in work room.

It also prohibits the employment of children (child means a person who has not completed fourteen years of age in any) industrial premises. If women and young persons (those between 15 and 18 years of age) are employed they shall not be asked to work except between 6 a.m. and 7 p.m. Every employee in an establishment can have leave with wages.

In the case of adult (a person above 18 years of age) at the rate of one day for every twenty days of work done by him during the previous calendar year, and in the case of a young person at the rate of one day for every fifteen days of work done by him during the previous calendar year. If any worker is discharged or dismissed from service or quits job during the course of the year, he shall be entitled to leave with wages at the as specified above.

If any employee does not take the whole of the leave allowed to him in one calendar year, the unutilized leaves shall be added to the leave to allow to him in the succeeding year.

However, the total number of days of leave that may be carried forward to a succeeding year shall not exceed thirty days in the case of an adult or forty days in the case of a young person. The provisions on annual leave are not applicable to home workers. During the leave period an employee should be paid wages at his rate equal to the daily average of his total full time earnings for the days on which he had worked during the proceeding month. This does not include dearness and other allowance.

An employee who has been allowed leave for not less than four days in the case of an adult and five days in the case of a young person shall be paid wages due for the period before his leave begins. A home worker can have wages during the leave period. The wages of a home worker during leave period will be calculated with references to the daily averages of his total full time earnings from days on which he had worked that is the average of 30 days earnings during the preceding month. An employee working for a period of six months or more shall not be dismissed except for a reasonable cause. Besides, an employee to be dismissed must be given at least one months notice or wages in lieu of such notice. If the service of an employee is dispensed with on a charge of misconduct supported by satisfactory evidence recorded at an inquiry held by the employer for the purpose, it is not incumbent on the part of employer to issue such a notice. A discharged, dismissed or retrenched employee may appeal to the appellate authority concerned.

The State Government may permit the wetting or cutting of Beedi or tobacco leaves by employees outside the premises. However, no manufacturing process shall be allowed to be carried on outside the premise. A home worker does not come under these regulations. If a person violates any provisions of the Ac or any rule made under the Act, he shall be punishable with a fine up to Rs. $250 \%$. For any subsequent offence he shall be punished with imprisonment for note less than one month but not exceeding six months or with a fine not less than Rs. $100 \%$ but not more than Rs. 500 or with both. An employer who fails to reinstate any employee under the order of the appellate authority is punishable with a fine up to Rs. $250 \%$. An employer, who even after being convicted under the Act fails to re instate an employee in accordance with the offence, shall be punished with affine up to Rs. 20 for each day such default from the date of conviction.

Under the Act the State Government may appoint any person to be a chief inspector who will have power examine, hold enquiries, and require any document relating to the manufacture of Beedi or cigar or both. The State Government, May by notification in the official gazette, make rules for carrying out the purpose of this Act. All workers engaged in Beedi making whether in their homes or under industrial premises should be indentified and identity cards should be issued to them. The contract system in Beei manufacturing should be abolished and initiatives should be taken to organize the Beedi workers to form their own co-operatives. All Beedi workers should be covered under social security scheme recommended by the commission. It is recommended that various laws relating to the Beedi industry should be brought under the ninth schedule of the constitution of India on the pattern of land reform laws.

The following table describes the type of work done by the respondents 
Table 1 shows: Type of the work by the respondents

\begin{tabular}{|l|c|c|c|}
\hline S.No & Type of Work in Beedi Production & Frequency & Percent \\
\hline 1. & Rewinding & 6 & $12 \%$ \\
2. & Cutting & 8 & $16 \%$ \\
3. & Rolling & 13 & $26 \%$ \\
4. & Folding & 23 & $46 \%$ \\
\hline & Total & 50 & 100 \\
\hline
\end{tabular}

For the above table it is evident that the respondents were involved in skilled work.

The following table describes the occupational life of the respondents

Table 2 shows: The occupational life of the respondents

\begin{tabular}{|c|c|c|c|}
\hline S.No & $\begin{array}{c}\text { Factors affecting } \\
\text { occupational life }\end{array}$ & Frequency & Percent \\
\hline 1. & Heavy work load & 9 & $18 \%$ \\
2. & Low Wages & 23 & $46 \%$ \\
3. & Lack of rest & 10 & $20 \%$ \\
4. & Health risk & 8 & $16 \%$ \\
& & 50 & 100 \\
\hline
\end{tabular}

All the respondents gave a negative response about their occupational life. In the case of $18 \%$ of the respondents they stated that their children were also involved in Beedi rolling.

Table: 3 The number of Beedi bundles rolled by the respondents

\begin{tabular}{|c|c|c|c|}
\hline S. No & $\begin{array}{c}\text { No of Beedi Bundles } \\
\text { Rolled in a Day }\end{array}$ & Frequency & Percent \\
\hline 1. & $20-25$ Bundles & 11 & $22 \%$ \\
2. & $26-30$ Bundles & 8 & $16 \%$ \\
3. & $31-35$ Bundles & 23 & $46 \%$ \\
4. & $35-40$ Bundles & 8 & $16 \%$ \\
\hline & Total & 50 & 100 \\
\hline
\end{tabular}

In a bundle there were 1000 Beedies. This table shows that the respondents were involved in the very hard work.

Table: 4 the following table describes the health problems of the respondents

Health problems of the respondents

\begin{tabular}{|c|c|c|c|}
\hline S. No & Diseases Suffering & Frequency & Percent \\
\hline 1. & Cancer & 1 & $2 \%$ \\
2. & Respirator Problem & 12 & $24 \%$ \\
\hline
\end{tabular}




\begin{tabular}{|c|c|c|c|}
\hline 3. & Diabetes & 7 & $14 \%$ \\
4. & Heart Problem & 7 & $14 \%$ \\
5. & Body Pain & 23 & $46 \%$ \\
6. & No Major Problem & 12 & $24 \%$ \\
\hline & Total & 50 & 100 \\
\hline
\end{tabular}

Majority $76 \%$ of the respondents faced some health problem or the other, which possibly due to their nature of occupation.

Table: 5 the following table describes the psychological problems suffered by the respondents

Psychological problems suffered by the respondents

\begin{tabular}{|c|c|c|c|}
\hline S.No & Mental Health Problems & Frequency & Percent \\
\hline 1. & Lack of Sleep & 20 & $40 \%$ \\
2. & Anxiety & 11 & $22 \%$ \\
3. & Insecure feelings & 16 & $32 \%$ \\
4. & Suicidal Ideas & 3 & $6 \%$ \\
\hline & Total & 50 & 100 \\
\hline
\end{tabular}

It is important to know that all the respondents faced some psychological problem or the other.

\section{CONCLUSION}

Through the legislation discussed above, seeks to protect the rights of Beedi workers, and in reality the provision of the Act are not implemented. Therefore, social activities need to take up the cause of Beedi workers and fight for their Rights.

\section{REFERENCES}

[1] Adram RM. (1983) Dermatitis due to irritation and allergic sensitization. In: Occupational Skin Disease, edited by Adams PM, Grune and Stratton, New York.

[2] 9Aghi MB, Gopal M(2001) Exploiting women and children-India's beedi industry. Lifeline 6:8-10.

[3] Augustine E.A. (1986). Rights of Beedi workers \& cigar workers, Indian Social Institute, New Delhi.

[4] Baran RL. (1983) Occupational nail disorders in: Occupational Skin Disease, edited by Adams RM, Grune and Stratton, Ney York, 101.

[5] Chattonadhvav BP. S Kundu. A Mahata. SK Jane Alam. (2006). A studv to assess the resniratorv imnairments amone the male heedi workers in unorganized sectors, | Volume : 10 | Issue : 2 | Page : 69-73. Regional Occupational Health Centre (E), Indian Council of Medical Research, Salt Lake City, Kolkata, India

[6] Dharmaliagam.A (1993), Female Beedi Workers in a South Indian-Village, Vol - XXVIII No. 27-28, July 03, Economic Political Weekly.

[7] Larsson L, Szponer B, Ridha B, Sitkowska J. Identification of bacterial and fungal components in tobacco and tobacco smoke. Tobacco Induced Diseases. 2008; 4 (1): 1 - 10.

[8] Maria Kuruvila. Saniav V Mukhi. Pramod Kumar. Gatha S Rao. KS Sridhar. MS Kotian (2002), Occupational dermatoses in Beedi rollers, Department of Skin \& STD, KMC Attavar Hospital, Mangalore, India |Volume : 68 | Issue : 1 | Page : 10-12.

[9] Mittal Saurabh, Apoorva Mittal, Ramakrishnan Rengappa. Ocular manifestations in bidi industry workers: Possible consequences of occupational exposure to tobacco dust. Indian Journal of Ophthalmology. Jul-Aug 2008; volume 56, issue 4: pp. 319-322.

[10] Nakkeeran Senthilkumar A Study on Occupational Health Hazards Among Women Beedi Rollers In Tamilnadu, India.

[11] Sen Vinod. Effects of Working condition on Health Of Beedi Workers :A Study of Sagar District of Madhya Pradesh. In: Arnab Ghosh, editor. Environment, Drinking water and Public Health: Problems and future goals. Daya publishing house, Delhi; 2007: pp 132-149.

[12] Swami S, Suryakar AN, Katkam RV, Kumber KM. Absorption of nicotine induces oxidative stress among bidi workers. Ind J Pub Health. 2006; 50(4): 231 5. [Medline].

[13] Umadevi, B., Swarna, M., Padmavathi, P., Jyothi, A. and Reddy, P.P. (2003) "Cytogenetic effects in workers occupationally exposed to tobacco dust", Mutation Research., 535(2), 147-154. 